\title{
Complex Ethnographic Research Methods for the Study of Protected Areas and Border Communities at the Slovenian-Hungarian Border ${ }^{1}$
}

\author{
Ágota Lídia Ispán - Dániel Babai - László Mód - Viktor Ulicsni - Csaba Mészáros \\ Institute of Ethnology, RCH, Hungarian Academy of Sciences, Budapest - \\ Institute of Ethnology, RCH, Hungarian Academy of Sciences, Budapest - \\ Department of Ethnology and Cultural Anthropology, University of Szeged, Szeged - \\ Institute of Ecology and Botany, Ecological Research Centre, Hungarian Academy of Sciences, Budapest \\ - Institute of Ethnology, RCH, Hungarian Academy of Sciences, Budapest
}

\begin{abstract}
The history of the Hungarian-Slovenian border region is to be understood as socionatural history: two co-evolving entities, society and nature have always been entangled in a web of connections and reciprocal influences. It is particularly true in this border area, where ecological diversity is the result of a century-long cultivation and correlating local lifestyles and economic strategies depend heavily on the ecological and climatic conditions of the region. In view of this interdependence, we aim to provide an in-depth analysis of both human and non-human agents in a region where ethnic, national, and state relations create a thickly interwoven fabric of human network with a background of a fairly uniform and intensively cultivated environment. By doing so, we would like to challenge the idea of Anthropocene as an overarching model and bring local images to the forefront. We argue that instead of Anthropocene, members of the local communities in this border region have entered an era in which they face difficulties acting as independent agents in their environment, since they have to rely on the mediation of state-funded institutions, such as the National/Regional Parks.

Keywords: Ethnoecology, Anthropocene, border studies, national parks, tourism, sustainability, methodology
\end{abstract}

\section{NATURE AND CULTURE IN THE ANTHROPOCENE ERA}

Anthropological studies focusing on the notion of environment and nature have gained prominence in the 1990s (INGOLD 1986, 2000). Researchers engaged in environmental anthropology have argued that the distinction of nature and culture is contingent and the result of a Cartesian episteme. Consequently, one of the main subjects of anthropological inquiry on the environment has been this dichotomy. Anthropologists debunking the contingency of the nature-culture dichotomy were usually engaged in two highly dissimilar scholarly discussions. 
The first focused on animistic hunter-gatherer societies. These studies demonstrated that various non-human entities are more often than not considered by locals not only as human but also as members of the local society (Descola - PÁLSSON 1996; KoHN 2013). These instructive examples have problematized the Western contrastive perspective on nature and culture. Arguably, in the environment of animistic hunter-gatherer societies, there is no conspicuous difference between wild and domesticated, between the areas modified by humans and the untouched "nature" (Descola 2013:28), at least not for those with a European perspective on nature and culture. Therefore, by applying our modernist paradigm on the worlds of these hunter-gatherer communities, we are not only overlooking how they perceive their environment but, more importantly, we are missing the point of what their environment consists of. If entities that have dissimilar bodies are actually equally regarded as human, then one cannot see them as external natural phenomena - as opposed to cultural phenomena. As a corollary, if an anthropologist wants to understand these communities, s/he should not omit entities from his/her analysis that, according to our Western ontology, are not human and thus not members of the local community.

The other field of anthropological scholarship that has problematized the dyadic opposition of "untouched" nature and culture (as the domain of human activity and agency) has been engaged in the study of cultural landscapes - predominantly in Europe. Cultural landscapes (although parts of them may appear as untouched forests and meadows in contrast to croplands and orchards) consist equally of tangible physical phenomena (vegetation, fauna, relief) and intangible cultural values. They are the outcome of permanent human presence, residence, and labor, and they are better understood as a process rather than a product (see TAYLOR 2012; TAYLOR et al. 2015). If we take seriously that in Europe nearly all landscapes are cultural landscapes, and forests, meadows, as well as rivers and lakes have been formed in the course of a complex relationship between humans and non-humans, then even without questioning the ontological status of dissimilar entities (plants, animals, animate and inanimate beings), one has to come to the conclusion that it is impossible to maintain the dichotomy of nature and culture any longer. And the reason for that is that one cannot point at nature without pointing at culture at the same time (see Kozorog 2015).

As a corollary of the reassessment of the notions of nature and culture, reassessing one of the most influential concepts of our time that is the Anthropocene is inevitable, especially considering the importance of the notion of the Anthropocene. As Bruno Latour writes, Anthropocene is "the most decisive philosophical, religious, anthropological and, as we shall see, political concept yet produced as an alternative to the very notions of 'modern' and 'modernity'”' (LATOUR 2013:77). If the Anthropocene idea has such an eminent role among contemporary concepts of nature and society, one should question the status of the idea.

The collision of human agency and natural forces is a key problem not only of anthropological research; independently of the insight on animistic hunter-gatherer communities and cultural landscapes provided by ethnographies, representatives of the geosciences also concluded that it is not only difficult but also pointless to maintain the binary opposition between nature and culture when understanding and describing contemporary ecological and climatic processes.

The term Anthropocene, coined and introduced by Paul Crutzen and Eugene Stoermer (2000), has fertilized debates on the role of humans in global ecosystems and became a powerful device for interdisciplinary discussions. Anthropocene is the period when 
human agency has become an influential (if not the most dominant) geophysical force, hence putting an end to the division between human and nature (PuRDY 2015:3). The label Anthropocene covers a large number of heterogenic phenomena, and thus has a homogenizing and simplifying effect (ARIAS-MALDONADO 2015:5-6). Among others, it makes cultural and ontological differences fade away. According to geoscientists and anthropologists, this epoch started in the $18^{\text {th }}$ century, has solidified in the $20^{\text {th }}$ century, and will continue into the future (MOORE 2015:515), or end with the extinction of the human race (DANOWSKI - ViVEIROS DE CASTRO 2017:5).

Although the idea of the Anthropocene aims at eliminating the boundary between nature and culture, it does so by retaining the fundamental difference between the two:

\begin{abstract}
"Insofar as the Anthropocene describes the degree in which human beings have colonized nature, it does not deny that such colonization may have taken place in different ways in different places and continues to do so. And the same applies, conversely, to the impact of climate change around the planet - the phenomenon is the same, its manifestations differ. However, the Anthropocene hypothesis suggests something that this book will emphasize, namely, that an actual homogenization in ways in which human beings and societies relate to nature is taking place, so that the local variations are less relevant than the global process of socionatural hybridization. Different societies may still think of nature differently, but what they do with it (to it) is rather similar." (ARIAS-MaLdonAdo 2015:7)
\end{abstract}

Some authors even argue that humans and non-humans remain essentially different in this process, and it was only the historical development of human technological capacities that eventually led to their domination of natural/physical forces (STEFFEN et al. 2007). However, anthropological insight suggests that there is much more at stake here. Cultural differences are not solely about how we think differently of nature or relate to it as a separate entity but also about of what the agora of this planetary change consists of. Consequently, we not only have to reassess the relation between nature and culture but also reconfigure our basic set of categories by which we grasp this process. Or, as Amelia Moore formulates it, we must reframe our basic concepts:

\footnotetext{
"Ideas about global environmental change influence thought and action in a number of arenas, and I hope to see anthropologists tackle the breadth of this planetary imagination animating emergent cosmologies of anthropos, bios, and geo. New frameworks are needed to keep pace with authoritative arguments about collectivity and responsibility in the face of a changing world." (MOORE 2015:27)
}

As a result, contemporary, ecologically informed anthropological scholarship needs to redefine its basic categories and methods in order to provide a powerful alternative to the modernist episteme that emphasized the uniqueness of human as an independent actor who rightly and autonomously controls natural forces as resources (BONNEUIL - FrESSOZ 2015:27).

In light of ongoing discussions on the nature-culture dichotomy and contemporary anthropological insight on the Anthropocene idea, the authors of the present article propose a complex research method for the study of protected areas along the Hungarian- 
Slovenian border, capitalizing on the rich and varied corpus of anthropological literature focusing on environmental conservation. Landscapes - having the legal status of protected areas - are intrinsically objects of human agency and cannot be evaluated merely on the basis of their ecological characteristics. The authors of this article argue that both the current flora and fauna and the legal status of the area are the outcome of constant negotiations between various human and non-human actors. Therefore, by focusing exclusively on local village communities (as did the majority of ethnographies so far in the area), it is impossible to provide a detailed ethnographic description of the area. With this in mind, the authors propose a complex research methodology combining diachronic/historical, ecological, and anthropological perspectives. By this, we subscribe to the opinion that transboundary large-scale ecoregional planning should take into consideration community participation and locally embedded benefit-oriented strategies that combine conservation and development targets (Brosius - Russel 2003:40-41).

\section{THE HISTORY OF THE CULTURAL LANDSCAPE}

The diverse agricultural lands of Central Europe have been shaped and sustained by traditional extensive farming systems for centuries. As a result of the geopolitical, economic, and social factors of marginality, in the area of our research (i.e., in the Hungarian-Slovenian border region), the characteristically mosaic-like, small parcel structure of the cultural landscape - the basis of self-sustaining farming and home to a remarkable biodiversity - can still be observed today (KALIGARIČ et al. 2008; PosCHLOD et al. 1998). The most important feature of these landscapes is structural complexity (FARINA 2000), the extent of which is characteristic of the state of the cultural landscape as well as of the possibility of preserving natural and cultural values.

The Hungarian and Slovenian parts of the Örség and the Vendvidék (also known as the Slovenian Rába region) are typically hilly landscapes (190-380 m altitude). The most significant streams in the valleys transecting the hilly region are the Zala and the Kerka. The area's soil is stratified. On the surface of the sand and clay, the ancient streams spread layers of gravel (ÁDÁm 1974). This gravel layer was covered by a significant formation of loam during the Pleistocene period. Due to the erosion caused by cropland cultivation, the gravel layer was re-exposed in many places (FranYó et al. 1976; SZÉPLIGETI 2015). Brown earth formed on the acidic bedrock (BoDONCZI 1999).

The climate of the area is balanced subalpine, one of Hungary's coolest and wettest regions. The average annual temperature is $9.1-9.8^{\circ} \mathrm{C}$ (DövÉNYI 2010). The annual rainfall is around 760-800 mm (DövÉNYI 2010) (usually 10-20 mm less in the Örség than in the Vendvidék), of which about $600 \mathrm{~mm}$ falls during the vegetation period (HAHN et al. 2012).

Due to similar factors, the natural features of the Vendvidék and the Örség are similar. The habitats and vegetation of the landscape are shaped by abiotic factors bedrock, soils, climate, terrain, wildlife, and thousands of years of human activity. Desiduous forests (Cyclamini-Fagetum) in this region are basically potential, so-called climate-regional plant communities in which sessile oak (Quercus petraea) mixed with pedunculate oak (Quercus robur), beech (Fagus sylvatica), and hornbeam (Carpinus betulus) form mixedwood forest stands. These extensive stands have been fragmented by 
nOw (BARTHA 2016). The sites of once-connected, extensive forests have been taken over by a mosaic of grasslands (hay meadows, orchard meadows, pastures) and croplands that meet the economic needs of the communities inhabiting the landscape. Fresh meadows (Arrhenatherion) are preserved to a greater extent in the region, whereas semidry, calcifugous lean grasslands (Agrostietum) that formed on the sites of former, abandoned and eroded croplands considered old-fields survived to a lesser extent (KovÁcs 1999; SzÉPLIGETI 2015; BARTHA 2016). In the valleys, along streams, extensive molinia meadows (Junco-Molinietum) and marshes (Deschampsion) are typical.

The proportion of the meadow-cropland-forest mosaic has changed considerably in recent decades. In the $20^{\text {th }}$ century, the size of the forests doubled, with almost three quarters of the landscape dominated by woody vegetation (BoDONCZI 1999; BALÁzs et al. 2011). The significant expansion is due in part to the increase in the volume of forests of native tree species, and, to a greater extent, to the appearance of cultured pine forests and other non-native tree plantations.

The flora of the habitats of the Örség and Vendvidék is shaped by the junction of regions, special climatic and soil conditions, and the resultant characteristic land use, all of which results in a distinct species composition and great biodiversity (SzÉPLIGETI То́тн 2016). The number of species occurring in the region exceeds one thousand (Örség: 1016 species, Vendvidék: 625 species - KÁroly - Pócs 1968, of which 130 became protected). Particularly valuable is the erect variety of the rose daphne (Daphne cneorum subsp. arbusculoides), which is a native subspecies in the region. The yellow daylily (Hemerocallis lilioasphodelus) is the jewel of the marshes and moors occupying the valleys, as is the marsh gentian (Gentiana pneumonanthe), while the purple marsh cinquefoil (Potentilla palustris) is less common (SzÉPLIGETI - TóTH 2016).

In addition to indigenous species, there are large numbers of undesirable adventive species (BALOGH 1996; SzÉPLIGETI - TóTH 2016). Of the 70 non-native species registered in the area, 27 are considered to be dangerous, invasive plants with the capacity to transform native plant communities. The most common is the giant goldenrod (Solidago gigantea) (BALOGH 1996; SzÉPLigeti 2015) and the hybrid Japanese knotweed (Fallopia x bohemica) (BAlogh 1996; KovÁcs 1999; SzÉPligeti - Tóth 2016).

Like flora, fauna mainly consists of Pannonian, wet continental, and subalpine elements. The most valuable species are mainly ones that depend on small-scale traditional land use (low-input farming, mowing, grazing). There are about 1500 lepidopteran species (VÍG 1998), including 120 butterflies and the symbol of the Örség National Park, the near-threatened scarce large blue (Phengaris nausithous) on the IUCN Red List (WCMC 1996). Other valuable protected species are the purple-edged copper (Lycaena hippothoe), the marsh fritillary (Euphydryas aurinia), and the lesser marbled fritillary (Brenthis ino) (BÁLINT 1994). The globally rare species of dragonflies have also great importance (Balkan goldenring (Cordulegaster heros), yellow-spotted whiteface (Leucorrhinia pectoralis) (AmBrus et al. 1995). The Ukrainian brook lamprey (Eudontomyzon mariae) is an outstanding conservation value of streams (Víg 2003). The most important species of amphibians are the NATURA 2000 species of the Italian crested newt (Triturus carnifex) that reaches the eastern border of its distribution here. Among the bird species, there is a need to pay close attention to the corn crake (Crex crex) due to the large number of the species in the region, even though its global and total Hungarian populations are declining. There is also a highly protected species of Western 
barbastelle (Barbastella barbastellus) (Víg 2003), which lives in hollows of old trees in the forest reserves. The European otter (Lutra lutra) also has a strong population in the Örség and Vendvidék (Víg 2003), even though this species has almost disappeared from vast areas of Central Europe.

The significant political, social and economic changes of the $20^{\text {th }}$ century had a great impact on the cultural landscape bisected by the state frontiers, homogeneous in geographical and ecological conditions. The state border became a determining factor on both sides in terms of landscape and natural scenery (BALÁzs et al. 2012). The hilly region of the northern part of the Prekmurje region in the northeast corner of Slovenia is the Goričko cultural landscape, one of Slovenia's most important agricultural areas (HAHN et al. 2012). It is one of the best-preserved small-scale cultural landscapes in Central Europe (Kaligarič et al. 2008). The area is 150 to $400 \mathrm{~m}$ above sea level (Hahn et al. 2012). The hilly landscape was essentially built by tertiary sediments on which sandy acidic soils were formed (ČInČ JuhANT - PlanjšEK 2002). The area's eastern climate, open toward the Pannonicum floristic zone, is continental - in Slovenian relations - with an annual average temperature of $9.6^{\circ} \mathrm{C}$, and an annual average precipitation of $730-950 \mathrm{~mm}-$ the lowest in Slovenia (KaLIGARIČ et al. 2008; HaHN et al. 2012).

The use of the area is similar to the ones in the Örség and Vendvidék; the former forests have been replaced partly by croplands and grasslands (today, half the area is occupied by forests, half by grasslands and croplands). The prevailing forest types, like in the Örség and Vendvidék, are beech and hornbeam. Pine forests and mixed oak-pine (Pino-Quercion) forests are also common (ČInČ JuHANT - PlanjšEK 2002). The turf varieties found here are similar to those found in the Örség, but the turf varieties of the drier sites (mesophilic and calcifuge grasslands) still have a stronger presence in the landscape. Its flora and fauna are also reminiscent of the landscape of the Örség and Vendvidék. The biodiversity of the drier grasslands is also outstanding in Goričko. To understand the processes of landscape history, it is necessary to outline the demographic characteristics of the area, since, as we have seen, the variegation and biodiversity of the area is anthropogenic in origin.

\section{THE HISTORICAL AND DEMOGRAPHIC BACKGROUND OF THE AREA}

Until 1918, the area of the Örség National Park and the Goričko Nature Park belonged to the territory of the Hungarian Kingdom, at that time part of the Austro-Hungarian Dual Monarchy. Following the 1920 peace treaty - which partially disregarded the ethnic characteristics of the region ${ }^{1}$ - the southwestern parts of the two Hungarian counties to the northeast of the Mura River (Vas and Zala) were transferred to the Slovenian territory of what was first the Kingdom of Serbs, Croats and Slovenes and later became the Kingdom of Yugoslavia. After the Second World War, the area became known by its

\footnotetext{
${ }^{1}$ According to the census of 1921, the total population on the $948 \mathrm{~km}^{2}$ of the Mura region was 92,295 , of which $80.4 \%$ were Slovenes. The Hungarian-speaking population lived in 26 settlements along the Hungarian-Yugoslav border, where $82.8 \%$ of the 15,780 inhabitants were Hungarians (KovÁcs 2013:28-31). In the territory of Hungary, there were 9 Slovene-speaking villages around Szentgotthárd, whose population in 1920 was 4,988.
} 
Slovene name Prekmurje (Trans-Mura), while in the Hungarian language Muravidék (Mura region) was adopted. The geographic region in the northeastern part of Prekmurje/ Muravidék was named Goričko, while the Hungarians living here - distinguishing them from the Lendva region - were called "Hungarians of Goričko" or "Hungarians of the Örség" or "Hungarians of the Downs", having had settled in eight settlements (three of them part of the historic Örség) (KovÁcs 2013:2-3). During the Second World War, this area was annexed to Hungary once again between 1941 and 1944; as a result of the new peace treaty, it was returned to socialist Yugoslavia and, after its dissolution, to Slovenia.

The Örség National Park was established on the territory of two ethnographichistorical regions - Örség and Vendvidék - that included some 44 settlements on their peripheries. The 18 settlements of the historical Örség (three of the villages now belong to Slovenia) and of the ethnographic and geographical region that is somewhat broader, are known nationwide, and the regional consciousness is a determining factor in the identity of the local population. ${ }^{2}$ In addition to the natural environment and the characteristic farming and settlement styles (hamlet, "fenced house", ridge plowing, selection cutting forestry, etc.), the privileges that were held until the $17^{\text {th }}$ century thanks to border protection duties, as well as administrative autonomy, community consciousness, good "marketing" of the region, and scientific-literary interest all contributed to the development of an explicit "Örség identity". The historical region called Vendvidék encompassed the Slovenian villages of Vas and Zala counties on the western boundary of Hungary, of which nine Slovenian settlements around Szentgotthárd remained within Hungary's borders following the First World War. ${ }^{3}$ After the Second World War, these communities came to be known by their Slovenian name as "Slovenes of the Rába" / "Porabski Slovenci" and "Rábamente" / "Porabje" (M. KozÁr 1994:333).

There are many parallels in the demographic conditions of the settlements in the two national parks. The peripheral situation within the given country and the fragmented settlement pattern made infrastructure improvements and investment in job opportunities in the primarily agricultural area more difficult, thus increasing the migration of young people (both in the form of emigration and internal migration), and at the same time reducing and aging the local population. The assimilation willingness of the Hungarian and Slovenian population forced into a minority situation was strengthened by the longstanding political and geographical isolation which manifested itself in an increase in the number of mixed marriages (KovÁCs 2013:59; M. KozÁr 1994:334; Munda HirnöK 2013, 2016; Munda HiRNÖK - MEDVEŠEK 2016).

The settlements of both parks had the highest population during the censuses of 1900-1948/49. Even with the slight decrease in natural reproduction and the losses caused by migration, population growth was still significant, but as a result of the accelerated migration of the 1950s, a population decline had already begun in the 1970s, and the

\footnotetext{
${ }^{2}$ The boundaries of the Örség are interpreted differently by the different disciplines. From the historical point of view, it only encompasses the 18 settlements in which the Hungarian population had a free legal status until the $17^{\text {th }}$ century, and mostly followed the Calvinist religion from the $16^{\text {th }}$ century. Based on their ethnographic features, the Calvinist villages located near the historic Örség are also usually included. NAGY 1999; CSAPÓ 2008.

${ }^{3}$ As a consequence of the consolidation of settlements, today the Vendvidék is made up of six settlements.
} 
trend continued into the 2000s. Since the 1941 census, the population of the villages of the Örség has fallen to nearly half (3,366 persons in 2017), while in the settlements of the Vendvidék the number of people decreased by $63.7 \%$ (1,895 persons in 2017), but in 2010, a population stagnation could be observed. ${ }^{4}$ From the 2000s on, aging and depopulation have been the most intensive (27,157 in 2010) in Goričko, especially in the northeastern and southwestern parts inhabited by the Hungarian minority, the natural growth rate being negative, one of the lowest in the country, while further west, the opportunities of commuting to workplaces in Austria somewhat mitigated these processes (HoRvat 2009:225-226; MALAČIČ 2011).

Emigration played a decisive role in the population loss, which was already typical of the region in the first half of the century: while before the First World War, the United States and Canada were the main destinations of emigration from the AustroHungarian Monarchy, in the interwar period, seasonal work in the Muravidék region was focused primarily on, Austria, Hungary, Germany, as well as Vojvodina, Bačka, Banat (in Yugoslavia) and even France. In Yugoslavia, even after the Second World War (especially from the second half of the 1960s), foreign employment was typical, and it was not only the poorer strata that took on employment in Germany in the hopes of a better paycheck but also the middle class (HUBER 2013; KERECSÉNYI 1994). Internal migration accelerated on both sides of the border in the 1950s, due to the increasingly frozen relations between the two countries starting in 1948 - the expulsion of Yugoslavia from Cominform and its subsequent break with the socialist countries.

From 1950 on, in the counties bordering Yugoslavia, the construction of the iron curtain began, along with the installation of technical barriers and restrictions on free movement in the 15-kilometer-long border area. Now considered the enemy, those of Southern Slav nationality, with relatives and relations in Yugoslavia, were subjected to atrocities by the authorities on a daily basis. Between 1950 and 1953, 921 people were deported from the settlements in the Örség National Park - mostly persons branded as Titoist kulaks (i.e., wealthy peasants plotting against the Communist regime in Hungary with the Yugoslavians) and their family members - to labor camps in Eastern Hungary (GYÖNGYÖSSY 2016:358-364; NAGY-SAÁD 2013). ${ }^{5}$ Although the camps were abolished in 1953 , only in the fall of 1956 was it possible for the displaced people to return to their homeland. After the gradual narrowing of the southern border zone, it was abolished in 1965, but the iron curtain and full border control remained in place until the regime change, which left the area out of the urban development concepts of the socialist era for a long time. After the regime change, cross-border relations became more vibrant and, above all, cultural in nature, targeting the Hungarian minority in Slovenia and the Slovenian minority in Hungary (MÉszÁRos 2015:75-77; Mód 2015). Due to the challenges of making a living, especially in the 1950s, the migration of the younger generation to the more industrialized centers intensified both in Hungary and Slovenia. By contrast, preserved natural values, traditional lifestyles, and low real estate prices have made these regions a destination for amenity migration: in the Örség, the acquisition of properties by

\footnotetext{
${ }^{4}$ Based on the censuses of the Central Statistical Office. For more information on the long-term demographic processes of the region, see Kovacsics 2000.

${ }^{5}$ For the expatriation of Slovenes in the Rába region, see Munda HiRnÖK 2011. From the Yugoslav side, on the expatriation of the Hungarian population of Petesháza in Lendva: KovÁcs 2011.
} 
urban, metropolitan intellectuals started in the 1970s (BELUSZKY 2005:151-154), while in Goričko, the presence of British, Austrian and German - as second home owners intensified following EU accession (LAMPIČ et al. 2015:134-137).

The gradual, and in some areas dramatic, decline in human resources raises the question of the sustainability of the variegated, biodiverse cultural landscape. In answering this question, it is of utmost importance to consider the agriculture and settlement pattern of the region.

\section{AGRICULTURE AND SETTLEMENT PATTERN}

Geographic and ethnographic literature often emphasizes that archaic (medieval) features and external influences occur in the settlement pattern of the region simultaneously (BELUSZKY 2005:56). There are several settlement types in the region, the most studied of which is the so-called "szer" (hamlet in English, hameau in French, Weiler in German). This settlement pattern can be seen not only in the Örség, Goričko, and the Vendvidék but also in other areas inhabited by Slovenes in Styria (Steiermark), although it would require further research to determine its exact distribution area.

Due to the abundance of land, families moving into the Örség and occupying the expansive clearings settled not in groups, i.e., clustered in villages, but separated from their neighbors, building residential and commercial buildings to establish farmsteads. Research in both settlement geography and settlement ethnography points out that a szer (hamlet) can be interpreted as a temporary phenomenon located between dispersed settlements and nucleated settlements in the system of settlement categories (BÁRTH 1996:200-201; MENDÖL 1963:225). On the site of every hamlet, there was originally a family's residence and economic buildings in one of the areas of a forest clearing. The settlers preferred the hillsides and hilltops over the soggy creekbeds. As the families grew, newer houses were built, which resulted in the expansion of the colonies. A hamlet was made up of territorially unrelated groups of buildings that belonged to an administrative unit. Each settlement was usually divided into five to ten hamlets, each of them with four to ten residential and commercial buildings. Some of the hamlets may have been established during the $12^{\text {th }}-13^{\text {th }}$ centuries. In the $14^{\text {th }}-15^{\text {th }}$ centuries, newer ones were created, and in the $16^{\text {th }}-17^{\text {th }}$ centuries, with the change in social conditions, the number of these particular types of settlements gradually declined. Archaeological, historical, and ethnographic research shows that hamlets were characterized by slow motion, which meant that they could expand with new houses and plots, or disappear, or even aggregate. Distances between hamlets can range from a few hundred meters up to one to two kilometers. Their size and structure are also varied (Borsos 2011:71-72). Some of the hamlets were built not on the hilltops but on the wider creek valley bottoms. In this case, the residential and commercial buildings are arranged in street-like rows, their incorporation, however, is rather uneven (ТóTH 1971:24). In the case of hamlets of a looser pattern, croplands, pastures and meadows may be wedged between the farmsteads. This type is considered older than the more clustered type that became characteristic during the late $19^{\text {th }}$ and early $20^{\text {th }}$ centuries following land consolidations. The hamlets usually bear the name of a family (Kovács, Pap, etc.), but other naming practices, such as 
orientation (e.g., Alsószer/Lower Hamlet, Felsőszer/Upper Hamlet) could have played a role in their designation.

Mária Kozár a native Slovenian researcher in Hungary, identified two major settlement types of Slovenians residing in Hungary. According to her classification, there are roadside villages, such as Rábatótfalu, Alsószölnök, and Szakonyfalu, and scattered settlements, such as Felsőszölnök, Apátistvánfalva, Orfalu, and Kétvölgy. ${ }^{6}$ Residential and farm buildings in these scattered settlements often formed clusters (in Slovenian krošeo), ${ }^{7}$ whose inhabitants were originally related. In these clusters, the buildings were surrounded by the initial, undivided family estate, with lands purchased or inherited later at various distances from it. The majority of these building clusters bore the name of the first owner. If the namesake family was extinct or the number of related families declined, the building cluster adopted the name of the family that owned several houses (MuKICS 2003:54-55).

Hungarian settlements in Slovenia (belonging to the Örség region), such as Hodos (Hodoš) and Domonkosfa (Domanjševci), represent a special settlement pattern in between the two aforementioned major types, where the residential buildings line up alongside the roads crossing the settlements. At the same time, the plots form a loose pattern, not always in close proximity of each other but with croplands, hay fields, and meadows wedged between them. This hamlet settlement type is best observed in Kapornak (Krplivnik) in the Municipality of Hodos. Similar observations can be made about the pattern of the Goričko settlements inhabited by Slovenes (Budinci, Dolenci, Markovci, Martinje, Cepinci, Neradovci, etc.), noting that dispersed settlements located at various distances from the building clusters also occur.

In addition to these settlement types, there are also linear settlements in the examined area, in the form of chain villages. The most important feature of this type is that the adjacent long and narrow plots are adjoined along their longitudinal sides, thus forming a series (HAVAS 2016:461). There are two major settlements on the Hungarian side of the border that play the role of urban center, Szentgotthárd and Öriszentpéter, and one in Slovenia, Murska Sobota (Muraszombat).

The settlements have transformed significantly during the $20^{\text {th }}$ century, which in many cases resulted in the merging of previously separated hamlets, thus creating a more closed landscape. $20^{\text {th }}$-century public reorganization affected several settlements, leading to the consolidation of previously separate villages. Between 1939 and 1950, Bajánsenye was created by the unification of Dávidháza, Kotormány, Senyeháza and Örbajánsenye, and in 1942, Kerce and Szomoróc were unified into Kercaszomor. In the Vendvidék, the unification of Ritkaháza and Permise in the early 1950s gave birth to Kétvölgy (Моноs 2008:65).

In the area studied, agricultural production was largely influenced by the natural conditions to which the local population had adapted. Besides the cool, rainy weather, the cohesive soils with poor drainage fundamentally determined the possibilities of agricultural production. The fertility of agricultural areas is very low in the region, especially between Felsőszölnök and Szalafö. Due to these unfavorable climatic and ecological conditions,

\footnotetext{
${ }^{6}$ For details on the settlement pattern of Felsöszölnök, see KozÁR 2000:118-121.

${ }^{7}$ Further research would be needed to clarify how this settlement form resembles the Örség-type hamlet.
} 
the extent of cropland never exceeded one third of the total territory even in the interwar period. Forests dominated the territory of Felsőszölnök, Orfalu, Ritkaháza, and Szalafö, occupying up to $40-50 \%$ of the landscape (BELUSZKY 2005:71-72). In addition to archaic slash-and-burn cultivation practiced until the early $19^{\text {th }}$ century, a characteristic cultivation technique of the region was ridge plowing, which allowed farmers to drain and collect excess water that accumulated on the parcels (DöмöTör 1954:149-164). Of the cereal crops, rye, different varieties of millet, and buckwheat played an important role, all of which adapted well to the harsh soil conditions. Of the New World plants, maize, potatoes, and pumpkin were common. Especially the latter was considered popular, as it was used for feeding livestock and pressing oil from its seeds (NAGY 2016:549-560). Of the agricultural sectors, grape and fruit production was well represented, the latter with an especially rich varietal range (ILLÉs 2016:597-627). The natural features of the region offered extremely favorable opportunities for livestock breeding, especially cattle, as the extensive grasslands and grazeable forests provided a suitable maintenance ration (KovÁcs - MESTERHÁZy 2016b:667-690). At the turn of the 20 $0^{\text {th }}$ century, there was a significant export of beef cattle to both Vienna and Graz, but during the interwar period, milk production came to the fore (DӧмÖтӧR 1987:42; BELUSZKY 2005:73-74).

In the overwhelming majority of the villages in the region on the Hungarian side of the border, independent smallholders dominated the local society, except for Felsöszölnök, where agricultural workers were a major group. In the second half of the $20^{\text {th }}$ century, the socialist reorganization of agriculture had a fundamental effect on agricultural production and, consequently, on land use. The difference between the agricultural policies of Hungary and Yugoslavia created dissimilar conditions, as in the Goričko settlements inhabited by Hungarians and Slovenians, families retained 10 hectares of land for use, thus small-scale farming did not cease to operate. It is not a negligible factor that from the 1960s and 1970s, Yugoslavian citizens had the option of working in Austria and West Germany, from where they brought not only new knowledge, but part of the money they earned was invested in modernizing family farms, acquiring the most advanced agricultural tools. Around the settlements of Goričko, the local population mostly produces cereals, corn, pumpkin, and rapeseed on small plots. The meadows are mowed, but grazing is not typical. Nearly every residential house has a vegetable garden and an orchard, primarily for the purpose of self-sufficiency. Some of the family farms are still engaged in cattle breeding, even though after the break-up of Yugoslavia, sales opportunities have been significantly reduced.

As a result of this divergent development in Hungary and Slovenia, compared to the Örség and Vendvidék, Goričko "has less forests and more croplands, the structure of the landscape is more open and mosaic-like, which is due to the tiny parcels, the grasslands around the settlements, the scattered houses and the orchards and forest patches amidst them". ${ }^{8}$ Thus, the diversity of the cultural landscape is much greater on the Slovenian side of the border, which is closely related to the continuity of smallscale farms and the different socio-economic environment (e.g., higher agricultural subsidies, better market opportunities, etc.).

\footnotetext{
${ }^{8}$ See in detail: BALÁzs 2017.
} 
In the 1960s, in addition to the State Farm of Szentgotthárd, other agricultural cooperatives were also organized in the Rába valley and in some parts of the Örség, whereas the Vendvidék, not being suitable for large-scale production, only provided the means for the operation of cooperatives whose members continued to engage in private farming. In most parts of the Örség, the parcels have been consolidated to create large plots for more efficient cultivation. In order to achieve higher crop yields, chemical and fertilizer use was significant in these regions. ${ }^{9}$

After 1990, further significant changes occurred in property relations, resulting in lands that were used by large agricultural holdings being almost entirely privatized either by releasing them to shareholders or issued as restitution. The local population was clearly on the losing end of these processes as it did not succeed in acquiring adequately extensive lands and agricultural machinery suitable for cultivating them. Land use by foreign - mainly Austrian - private or legal entities, manifested primarily by the cultivation of different arable crops (maize, rapeseed, oil pumpkin, buckwheat, etc.) is considered a new phenomenon. Today in the Örség and in the Vendvidék, agriculture is increasingly losing its significance, and agricultural production is becoming more of a source of supplementary income or subsistence. Cattle-breeding has been significantly displaced due to shrinking sales opportunities, lack of modern equipment, and purchase price fluctuations, which resulted in a sharp decline in livestock numbers. In both regions, future opportunities for agriculture are closely linked to nature conservation, since a significant part of the protected areas (e.g., grasslands) have been established as a result of human activity. In this regard, the Örség National Park itself is also trying to play a proactive role through various projects (KovÁCS - MESTERHÁZY 2016c:663).

The combination of the ecological, historical-demographic, and economic factors presented above did not only result in a mosaic-like, highly varied landscape and ecosystem but has also created the possibility of declaring the area protected. However, these factors alone do not explain the protected status of the area. To understand the long process resulting in the creation of National Parks on both sides of the border, it is important to present the political and economic environment in which the area gradually gained more and more protection.

\section{THE HISTORY AND STATUS OF PROTECTED AREAS IN HUNGARY AND SLOVENIA}

The reconsideration of the role of the undeveloped and peripheral Örség region gained momentum in the 1970s. The county- and district-level party and state apparatus, in the spirit of socialist modernization, propagated the industrial development of regional centers in the county and the extension of agricultural co-operatives and state farms in rural areas. Accordingly, a great deal of land previously uncultivated (as a result of mass emigration and low fertility) became state-owned (PóSFAI H. 1974). The other concept - considerably different in terms of its objectives - was born in the spirit of the change in the human ecological mindset that was steadily emerging in the socialist countries, which

\footnotetext{
${ }^{9}$ For the cooperatives formed in the Örség, see in detail: KovÁCS - MesterhÁZy 2016a:635-645.
} 
included the planned increase of nature conservation areas and developing environmental awareness. Under the auspices of the National Nature Conservation Office, the Örség Landscape Protection Area was established in the first half of the seventies, and it finally opened in 1978 (its 38,000 hectares of land forms the basis of today's national park). The protection extended to natural plant associations, fauna, natural irrigation and drainage conditions, as well as to the conservation of landscapes and the cultivation of traditions (SimON 1980). After the regime change and following lengthy preparations, the establishment of the Örség National Park was initiated by civil organizations, which was eventually inaugurated in 2002. Two-thirds of the 44,000 hectares of land are forest, one tenth grassland. At the time of foundation, more than half of the land was privately owned, $39 \%$ was owned by the state, and $5 \%$ by business organizations, but the national park is gradually increasing the size of the areas under its management by buying up land, with expectations of more effective nature conservation and a decline in conflicts regarding protected areas ${ }^{10}$ (MARKOVICS 2016:13-17).

The Goričko Landscape Park was established in 2003 on 46,200 hectares, with 91 settlements administered by eleven municipalities. Although the isolation of the border region, similarly to the Örség, resulted in the preservation of the unique landscape and natural values, the question of protecting the area was never raised in the socialist era (DeŠNIK - DomAnjKo 2011:40). Just like in Hungary earlier, the establishment of the park was preceded by conflicts of interest. This culminated in a negative propaganda: the locals were mostly worried that the expected park-related regulations (reduced agricultural yields due to limitation of the use of chemicals, declining industry due to limitation of investments, and rising migration among young people due to lack of job opportunities) would undermine the dominant sources of livelihood in the region. The purpose of the organized public awareness-raising campaigns and seminars was to reduce the resistance of the local population and to dispel their various fears (LEBE n.d.). Despite the fact that they have subsided over time, conflicts with the local population (such as over the maintenance of meadows and grasslands) still occur to this day. Although the problems are of a similar nature, due to their different status, the two parks are able to respond to them differently.

According to the classification of the International Union for Conservation of Nature and Natural Resources, national parks like the one in the Örség are considered Category II, while protected landscapes like the one in Goričko belong to Category V. The former is an area whose ecological coherence must be preserved for present and future generations; which must be protected from all kinds of agricultural and industrial use; and where it is possible to carry out not only scientific but also educational and leisure activities. The latter, on the other hand, is an area whose coherence must be preserved because of its natural or cultural values. ${ }^{11}$ National legislation also gave the two protected areas a different purview. The Örség National Park is both a public service provider and a public authority. ${ }^{12}$ Its most important duties include safeguarding protected values,

\footnotetext{
${ }^{10}$ From the point of view of the local population, they are as follows: the national park regulates too much (limiting wood cutting, mushroom picking), their lands seem unattended and messy, many of them are foreigners, they do not cooperate with the locals. BARANYAI 2012:117-118.

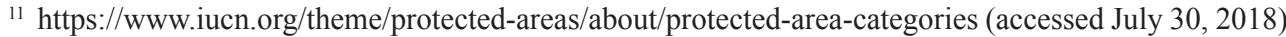

12 http://magyarnemzetiparkok.hu/a-npi-feladatai/ (accessed July 29, 2018)
} 
managing protected areas, coordinating and developing species and habitat protection programs, contributing to research, developing and maintaining habitats, educational and informational activities, as well as contributing to the preservation of ancient Hungarian domestic animal breeds and varieties. By virtue of its public authority, it reviews violations of conservation and operates a Nature Conservation Service staffed by ten persons, all of whom wear a uniform and are equipped with a service badge and ID, a service car, and a handgun; they have a right and duty to monitor compliance with nature conservation regulations, to check and detain persons or vehicles in case of a violation of nature conservation interests, to impose on-site fines, and to initiate infringement, administrative or criminal proceedings. ${ }^{13}$

The duties of the Goričko Park - monitoring, surveying, protecting, presenting, and developing the natural and constructed environment - are partially identical to the Örség National Park; the big difference is that it does not have any authority, does not exercise ownership rights, and does not see to the genetic protection of ancient animal breeds. While the two parks are nearly the same size and face similar problems, the Örség National Park has four times as many permanent staff and its annual budget is twice as much as the Slovenian entity's, thus it fulfills more complex functions (Hesz 2016:3843). Though the bilateral cooperation between the two parks - as well as the trilateral cooperation in the case of the Goričko-Raab-Örség park - is hampered by the lack of a joint cross-border organization and disparate institutional structures and legislative frameworks, during the increasingly project-based cooperations, which saw an upswing especially after accession to the European Union, territorial and strategic thinking has been prioritized (Hesz 2016:113-114; Peterlin - Simoneti 2016) .

The differences in the operation of Goričko Park and Örség National Park, as well as the various farming systems of the second half of the $20^{\text {th }}$ century, have significantly influenced the impact the Parks have had on the environment and the local communities.

\section{THE IMPACT OF THE NATIONAL PARK'S MANAGEMENT ON THE VEGETATION AND FLORA}

The size of the territories under the asset management of the Örség National Park has been growing steadily since its foundation. In 2002, there were 887 hectares under national park management, whereas in 2016 that number was 5,331 (1,110 ha grasslands, 2,104 ha forests, 970 ha croplands) (Goričko Nature Park is much smaller in size) (MARKovics 2016).

As nature conservation regulations apply not only in areas under their asset management but in all protected areas, husbandry is also regulated by a number of rules. A significant part of the Örség, about $70 \%$, is today covered by forests. Their eco-friendly management aims to provide a continuous forest cover (gap creation, selection cutting), to reduce the extent of plantations of invasive alien species, and to develop mixedwood stands of domestic, native species. From an ecological point of view, the presence of the right amount of standing and lying deadwood in the forest is important, as these provide micro-habitats and sources of food for many bird and insect species.

${ }^{13}$ http://www.orseginemzetipark.hu/hu/info/rolunk/orizzuk-a-termeszetet.html (accessed July 29, 2018) 
The nature conservation practice on the mostly anthropogenic, secondary, yet species-rich grasslands managed by the Örség National Park aims to create and operate the largest landscape, habitat, and species diversity possible. Applying several elements of traditional grassland management would help achieve these goals, but most of them are barely supported by current regulations (mainly NATURA 2000 regulations) (BABAI et al. 2015). The current regulations have a direct positive effect on the activities that are essential for the maintenance of grasslands (once-yearly utilization, shrub control) (BABAi et al. 2015; SzÉPLIGETI 2015). Extensive farming elements that are ecologically beneficial and should be encouraged include the use of lawnmowers, second mowing (mowing of aftergrass), aftergrass grazing, the use of hayseed in lawn regeneration, and continuously changing the spatial and temporal intensity of treatments (SZÉPLIGETI 2015).

The majority of the grasslands are mowed or extensively grazed once or twice a year, or mowing and aftergrass grazing are taking place concurrently, with the intensity and intensity-diversity corresponding to the sensitivity of the habitat types. In order to protect the large blue/Phengaris species (Maculinea sp.) in their habitats, mowing should be carried out at the end of May (early June) or in late August (early September), preferably in small, mosaicked patches, with different intensities and timing (KöRÖsI et al. 2014). In the case of grasslands, low utilization intensity, the consequent increase in shrublands, forestation, and the spread of the giant goldenrod are a general problem (SzÉPLIGETI 2015).

Small-scale agriculture and cultural landscape are much better preserved on the Slovenian side, though economic interests and depopulation resulted in a significant growth in the size of land plots, and thus in a decline in the variety of habitats (especially of the borderlands and bounds). Because of this, there is a much smaller area under the asset management of the Goričko Nature Park, and although the enforcement of conservation aspects is a more difficult task due to unfavorable economic and social processes, the intensification of farming or its abandonment pose a real risk. The latter, in particular, poses a significant risk because the region is in need of human resources (as the demographic survey shows). One of the potential development opportunities in the region (both for nature conservation institutions and for local communities) is tourism.

\section{THE ROLE OF TOURISM IN THE REGION}

The most characteristic region of the Örség National Park today is the Örség. The beautiful patterned landscape and the fresh air has attracted holidaymakers since the interwar period. First they turned to the villages of the upper Rába valley and later to the Örség further south, primarily because of their bath culture (KEVY 2016:837-844). This process halted after the Second World War, and the just-evolving tourism of the area was eradicated for twenty years by the border zone established under the Communist regime, which limited the movement of the civilian population in the area. After the abolition of the border zone, the touristic repositioning of the restricted area was more and more successful, and nature conservation values and folk traditions played an ever greater role in it. Several actors have contributed to the process that could be interpreted 
as patrimonialization. ${ }^{14}$ The abundant ethnographic, historical, and geographic interest in the Örség that emerged in the interwar period was followed in the late 1950s by the attention of the National Office for Cultural Heritage Management tasked with protecting folk monuments, the National Nature Conservation Office tasked with managing nature conservation values, the various ideas of county and district councils, and the participation of the Vas County Tourist Association active in the region since the mid-sixties. They attempted to overcome the underdeveloped tourism infrastructure by developing a hospitality industry (by including private accommodations), building catering facilities, etc., and promoted the affordable holiday facilities in the Örség in national newspapers. Since the 1980s, the National Tourism Office has also considered the Örség as one of the highlighted areas of rural tourism to be developed, but at that time it still faced several (mainly infrastructural) difficulties. ${ }^{15}$

Although the tourism potential of Goričko has received less attention in the past - the most important destination was the thermal spa of Moravske Toplice with a history of a few decades - following the regime change and the establishment of the national parks, a very similar institutionalization process emerged in tourism. As one of the elements of this, the scope and organizational background of those involved in the tourism industry have changed: instead of centrally managed tourism offices, new actors have emerged in the likes of local authorities, professional associations, county and municipal tourism offices, NGOs, businesses, etc. The greatest potential for development in both regions lies in their environmental capital (biodiversity, natural resources, ecosystem services, land) - be it agriculture or tourism, and most of the successful tourism projects are directly related to this (e.g., bicycle paths, mill trails) (LAMPIč et al. 2015:130, 133). The two national parks have built their service activities on ecotourism, which includes environmental education (forest school programs, nature conservation competitions, guided tours, etc.) and infrastructure development (tourist paths, educational paths, scenic overlooks, accommodations, tourist offices, etc.).

The historical and cultural heritage is an integral part of this, with some of its elements evolving into touristic brands (hamlet-type architecture, pottery, log pulling, traditional dishes, etc.) that symbolize the entire region, around which event- and festival-tourism has been built (e.g., Örség Fair, International Pottery Fair in Magyarszombatfa (see also BAJUK SenČAR 2015), Örség Pumpkin Festival). One of Goričko's most successful brands is the Diši po Prekmurje (Scent of Prekmurje) trademark, which was established in 2005 under a PHARE program that brought together local food producers, suppliers, and experts in the fields of quality food and traditional gastronomy with the aim of elevating the quality of food, and protecting and promoting Prekmurje's gastronomic specialties (LAMPIČ - Mrak - PotoČNIK SlaviČ 2015:133). To date, there are two standardized and protected products: Prekmurje ham and Prekmurje gibanica (layered pastry), but protected are also the wines of the Prekmurje appellation, and many other local specialties are being offered. ${ }^{16}$ The use of the trademark of the Örség National Park is

\footnotetext{
${ }^{14}$ For a study examining the main actors of this practice (the heritage specialist reconstructing the site, the local heritage carrier, the audiences receiving the interpretations of the heritage) in relation to declaring the UNESCO World Heritage Site, Hollókő, as protected: SoNKOLY 2016:112-116.

${ }^{15}$ Details of the development of tourism in Örség: Kevy 2016.

${ }^{16} \mathrm{http} / / / w w w . d i s i-p o-p r e k m u r j u . s i / e n / i n f o r m a c i j a . a s p ? i d \_m e t a \_t y p e=46$ (accessed July 26, 2018)
} 
somewhat broader, since potters and caterers can also receive it besides food producers, ${ }^{17}$ and it is part of a nationwide program: the park joined the Ministry of Agriculture's 2011 initiative which intended to contribute to the maintenance and protection of natural resources and to the development of rural ecotourism and rural self-employment by means of the National Park Product trademark. Products were required to have been made from local raw materials in an environmentally friendly way that represents the natural, scenic, and cultural characteristics of the region, and given activities to have been based on local traditions and regional workforce. ${ }^{18}$

According to a survey in the Örség, despite these efforts, and even though the volume of rural tourism is growing year after year, the attraction of the countryside and rural accommodations is by no means sufficient - the locals are less involved in the events targeting the general public, and in practice, the complexity that is rural tourism is today limited mainly to accommodations and catering (BARANYAI 2012:101-114; BARANYAI - BARANYAI 2013:74-76). One of the prerequisites for maximizing the potential of tourism and at the same time maintaining agricultural production (as well as biodiversity) would be that local communities put agricultural production and processing in the service of tourism.

\section{AGRICULTURE AND FOOD PRODUCTION IN SERVICE OF TOURISM}

Due to the negative processes affecting local agriculture since the 1990s, meeting the demands of tourism may be one of the ways out for agricultural production if the oftendisadvantageous legal framework were to also change in a favorable direction. The region's small-scale, multi-faceted farming traditions may offer ideal conditions for this, not to mention that the revival and practice of traditional landscape utilization techniques may significantly contribute to the preservation and maintenance of natural values. In spite of the socio-economic changes in the Slovenian settlements in the second half of the $20^{\text {th }}$ century, the food culture of the region includes many traditional elements that could provide excellent opportunities for the development of gastro-tourism. Of the so-called archaic grain crops, the cultivation of buckwheat is largely characteristic in Slovenia, where its seeds are consumed as part of daily nutrition. It is so popular that it is carried by stores throughout the entire country and it is often on the menus of restaurants, too. It is getting more and more attention in Hungary, though its consumption is still fairly limited. The poor-quality soils of the examined area offer the appropriate conditions for its cultivation; the grain of the buckwheat and the honey from its flower have a wide use in gastronomy, and they can be successfully marketed as local products. In recent years, several projects have made attempts at rescuing and preserving the diverse fruit trees in the Örség and its surroundings. In addition to the harvesting of fruit crops, farmers also harvested hay on a regular basis from orchard meadows, thereby providing a habitat for numerous plants that are protected today. Old fruit varieties are not only relevant for gene preservation - because of their properties and different ripening times, their various

\footnotetext{
${ }^{17} \mathrm{http} / / /$ www.orseg.info/hu/info/orokseg/nemzeti-parki-termek-vedjegy/index.html (accessed July 27, 2018)

${ }^{18} \mathrm{http} / / /$ nemzetiparkitermek.hu/vedjegy/ (accessed July 27, 2018)
} 
uses (dried fruits, jams, vinegars, syrups, brandy) offer unmatched opportunities for family farms. The ungrafted grape varieties introduced in the region after the phylloxera epidemic, which are suitable for the production of organic wines, vinegars, syrups and jam, are still underexploited to this day. Old fruit varieties and American varieties of grapes perfectly meet the requirements of organic and eco-farming technologies as they require minimal plant protection. By analogy with the "National Park Trademark", the Örség National Park recently created the "Örség National Park trademark", which supports local farmers operating in the nature conservation areas and promotes the marketing of their products intended for sale (BARANYA 2012:135-136). Since 2012, there is a local farmers' market in Öriszentpéter where family businesses offer a wide range of their products. The founders wanted to create not only a new tourism product but also more favorable sales opportunities for local farms.

Pumpkin seed oil, also known as "the gold of the Örség", is now providing a livelihood opportunity for a few specialized farms, which, in addition to producing and distributing their products, try to also present the traditional tools of oil-milling and the methods of oil extraction to tourists. ${ }^{19}$ On the Balogh family farm in Szalafö, the oil mill also functions as a demonstration workshop where visitors can get acquainted with the most important work processes. In 2017, these demonstrations attracted a large number of tourists to family farms, which, thanks to these occasions, were able to sell their products more successfully. The production and marketing of pumpkin seed oil in itself would not be able to sustain these family farms, which is why they have to undertake a specific diversification, often involving the production of other types of oil. Thus, in recent years, pumpkin seed oil has been accompanied by oils pressed from walnuts, grape seeds, poppy seeds, peanuts, sea buckthorn, hemp seeds, and apricot kernels. The solid residues remaining after oil extraction are sold as flour or press cakes, which can be used for both culinary and medicinal purposes. In the case of the Batha farm in Szalafo, in addition to the oils, they also offer various jams, fruit vinegars, and fruit brandy (pálinka). The family farm also maintains a farm for breeding mangalica, a Hungarian endemic breed of pigs. Their products are not only sold locally, they are also offered for sale in markets such as in Szombathely.

The family running the Ferencz farm in Szalafö moved from Budapest to the Örség in 1989, leaving behind the metropolitan environment for traditional livestock breeding. Between 1995 and 2008, they focused mainly on goats, then cattle breeding became a key sector. The family farm encompasses 90 hectares of land that is either owned or rented, consisting of both pastures and hayfields. Most of the cattle are bred for meat, only a few cows are milked to make butter and seasoned cheeses. The products made on the farm are branded as "organic", although the family left the control system for financial and administrative reasons. Since 2000, they have been providing accommodations for tourists, allowing them the opportunity to join the work processes around animals. Their operation proves that if milk is being processed locally, they can sell it more successfully than they would by passing it on to the dairies.

These few examples briefly presented here seem to suggest that in this border region under natural protection, agricultural production can provide a solid income for the local

${ }^{19}$ Formerly, the cultivation of pumpkins and the production of oil from the seeds had primarily served the purpose of self-sufficiency, the "end product" was rarely sold. 
population if it is combined with various services (accommodations, model farms). As we have highlighted earlier, the sale of locally produced raw materials and the products made from them can be a way out and a future perspective for agriculture.

\section{PROPOSED RESEARCH METHODS FOR THE COMPLEX STUDY OF PROTECTED AREAS}

During our presentation of the region's capacities, we wanted to advocate for the fact that historical, demographic, and management processes developed in conjunction with each other during the past centuries, creating the conditions for the legal protection of the region. This protection then posed a challenge to local communities but also created the opportunity for the development of tourism and agricultural production and processing activities serving tourism. Based on all this, it may seem at first glance that, in this region, development and environmental aspirations can easily be coordinated through a unified cross-border ecoregional plan. However, intensive ethnographic research has pointed out that the relationship between national parks and local communities in the region is often not free from tensions (Mészáros 2015; Turai - Mészáros 2015). In the following, we argue that soft data, which can point to differences of interest between various institutions, people, and non-people in the region, can only be revealed through a complex historical, ecological, and anthropological research and fieldwork method that requires the collaboration of several experts both in Hungary and in Slovenia.

Historical research focuses on the socialist era, examining how the image of the Örség changed in the era, who its leaders were, what its key elements were. The repositioning of the role of the region as building on natural values and traditional lifestyles associated with environmental and nature conservation movements was the basis for the main character of development still prevailing today, which has kept the emphasis on preservation. This can be considered an ongoing practice of patrimonialization and an institutionalization process at once, with the involvement of several actors. Among the major players are the county and district power elite, national and county offices such as the National Nature Conservation Office, National Office for Cultural Heritage Management, Vas County Tourism Office, as well as the local municipalities and population.

Research is accordingly carried out at several levels. As reflected in the minutes of the meetings of county and district party and state organs found in the Vas County Archives of the Hungarian National Archives, the situation of the region was discussed from time to time, where different concepts of development were discussed and decisions made on implementation, and particularly informative are the written records of comments spoken during the debates of the plans. The documents in the Hungarian National Archives are expected to provide new information about the professional guidelines and the institutionalization process (creation of landscape protection area, development of tourism infrastructure). Conflicts of interest and contention - in many respects similar to contemporary conditions - developed at the local level along different concepts, involving both cooperatives (which had to take into account the provisions of the landscape protection area) and the local population (who wished for modern housing instead of preserving the architectural heritage). The identification of these conflicts is partly based on archival sources, but in the next phase of research, the local point of view 
and the local oral history of experiences must be extracted from narrative sources (e.g., interviews, reminiscences); during this phase, it is also important to address those actors who participated in institutionalized tourism since the $1970 \mathrm{~s}-80 \mathrm{~s}$ as providers of private accommodations or as city dwellers buying cheap real estate, thus benefiting from the processes taking place in the region.

In the 1990s, a transformation in the relationship between researcher and researchee occurred in the social sciences as methods based on collaborative research or cooperation spread, although in cultural anthropology, cooperation with members of local communities cannot be considered completely unprecedented (LAJos 2014:37-38). In our research, we consider several collaborative strategies, such as involving our contributors in the research process as readers or editors, organizing community forums, or jointly producing and writing texts. Similar research has been carried out recently in the Örség and Vendvidék, which, by taking advantage of the opportunities hidden in the methodology of participatory action research, sought to draw attention to the importance of traditional knowledge and cultural and natural resources (PATAKI et al. 2011:9-27). In our opinion, social and natural science research in the examined region cannot do without the close cooperation of local farmers, whom the experts like to involve in the process of nature conservation. Greater emphasis could be placed, for example, on the local preservation of the previously mentioned fairly diverse fruit varieties by letting the local population care for their own orchards and varieties (PATAKI et al. 2011:12). Cooperation with ethnographic researchers may be undertaken in many ways. Of all the possible options, the utilization of traditional land use techniques today is but one. In this regard, we believe that cooperation between the researcher and the farmer who is interested in this issue is indispensable, as today's experiential knowledge may provide assistance in interpreting historical sources, but the information gleaned from archival documents (such as the use of certain landscapes in the past) may be utilized in the management systems of today as well. The results may be analyzed by the researcher and the farmer either in a jointly compiled study or in a professional lecture and may be presented to members of local communities and professionals. Exciting questions may be raised, for example, by the attempt to reconstruct local knowledge regarding fruit varieties, as ethnographic descriptions of utilization are often scant, rarely providing detailed instructions on the technologies used in processing. These shortcomings may be remedied by the cooperation of the researcher and the farmer specializing in the production of local specialties.

Part of our research focuses on traditional ecological knowledge of the flora and fauna and the practice of extensive, low-input farming. In this case, it is worth seeking out knowledgeable members of the older generations. For exploring current practices and local perceptions of nature conservation policies, rules and aspects, practicing farmers and other interest groups (foresters, hunters) must be sought out. In both cases, the interview is the most commonly used method. Structured and semi-structured interviews, free listing and pile-sorting are most important. We interviewed Hungarians and Slovenians practicing traditional agriculture in the villages of the Örség and Vendvidék on both sides of the border. We collected data on traditional ecological knowledge from 2017 while trying to find the most knowledgeable persons in the village, beginning with the suggestions of local community leaders, and selecting the rest by the snowball method. 
In order to learn about plant knowledge and extensive farming, we must explore the folk taxonomy of plants, their biological content, and the perceptions of changes in the species pool. To avoid any communication problems, the overlaps and differences between the species considered important by nature conservationists and the species known to the local community must also be explored. Another objective is to explore the sites differentiated by the locals, the principles and units of landscape partition, as well as to learn about the practices of habitat management and extensive landscape use.

To achieve the above goals, we used primarily field and in-room interviews. Field visits are important for getting to know the area through the scale of parcels, as well as in terms of ecological memory and land use history. It is also one of the best ways to clarify the details of folk biological classification, to precisely define the biological content of each of the folk taxa. If this is not possible, in-room interviews come to the fore in which the questioning is conducted with the help of freshly picked, live plants, or, if not even this is possible (e.g., in the case of protected species), using color photographs. The point is to learn about the local name of the species, the knowledge of its use, and habitat preferences.

In terms of wildlife knowledge, our aim is to explore the assessment of wild animal species through the nature conservation aspect. In addition to eliciting information on which wildlife species the locals consider worthy of protection, we also investigate local opinions and perceptions regarding the species professional nature conservationists deem important and protection-worthy.

\section{REFERENCES CITED}

ÁDÁM, László

1974 Nyugat-Dunántúl ösföldrajzi fejlődéstörténete [The Paleogeographic Evolution of Western Transdanubia]. Vasi Szemle 28(4):584-602.

Ambrus, András - BÁNKuTi, Károly - Kovács, Tibor

1995 Az Örség szitakötő faunája (Odonata) [The Dragonfly (Odonata) Fauna of the Örség]. Savaria - A Vas Megyei Múzeumok értesitöje 22(2):49-62.

Arias-Maldonado, Manuel

2015 Environment and Society: Socionatural Relations in the Anthropocene. London: Springer.

BABAi, Dániel - Tóth, Antónia - Szentirmai, István - Biró, Mariann - Máté, András Demeter, László - Szépligeti, Mátyás - Varga, Anna - Molnár, Ábel - Kun, Róbert Molnár, Zsolt

2015 Do Conservation and Agri-Environmental Regulations Effectively Support Traditionally Small-Scale Farming in East-Central European Cultural Landscapes? Biodiversity and Conservation 24(13):3305-3327.

Bajuk SenčAr, Tatiana

2015 The International Wildflower Festival and the Implementation of Sustainable Mobility as Touristic Practice. Traditiones 44(1):87-116. 
BALÁZs, Pál

2017 Azörségi táj változásának és karakterének elemzése [Analysis of the Landscape Changes and Character of the Örség]. (PhD dissertation). Sopron.

Balázs, Pál - KonKoly-Gyuró, Éva - BAcsÁrdi, Valéria - Király, Géza

2012 A táj átalakulásának feltárása történeti térképelemzés és kérdöives felmérés alapján az Örségben és a Vendvidéken [Exploring Landscape Transformation through Historical Map Analysis and Questionnaire Survey in the Örség and Vendvidék]. TransEcoNet project, project report (WP4, WP6). Sopron: Nyugat-magyarországi Egyetem Kiadó.

BÁLINT, Zsolt

1994 Magyarország lepkéi a természetvédelem tükrében [The Butterflies of Hungary in the Scope of Nature Conservation]. Somogyi Múzeumok Közleményei 10:182-206. Kaposvár: A Somogy Megyei Múzeumok Igazgatósága.

BALOGH, Lajos

1996 Adatok néhány inváziós növényfaj elterjedéséhez az Örségi TK-ban és a kapcsolódó területeken [Data on the Spread of Certain Invasive Plants in the Örség Nature Reserve and Related Areas]. Savaria - A Vas Megyei Múzeumok Értesítöje 23(2):297-307.

BARANYAI, Olga

2012 A változó Örség fejlesztésének természeti és társadalmi alapjai [Natural and Social Bases for the Development of the Changing Örség]. PhD dissertation. Pécs: Pécsi Tudományegyetem, Földtudományok Doktori Iskola. Manuscript. BARANyAi, Olga - BARANYAi, Gábor

2013 Role of Rural Tourism and Agriculture for Development of Rural, Protected Areas. Revija za geografijo 8(2):71-80.

BÁRTH, János

1996 Szállások, falvak, városok. A magyarság települési hagyománya [Homesteads, Villages, Towns. The Settlement Traditions of Hungarians]. Kalocsa: Kalocsai Múzeumbarátok Köre.

BARTHA, Dénes

2016 Az Örségi Nemzeti Park élőhelytípusai [Habitat Types in the Örség National Park]. In Bartha, Dénes (ed.) Az Örségi Nemzeti Park I, 291-339. Öriszentpéter: Örségi Nemzeti Park.

BeLuszKy, Pál

2005 Örség - Vendvidék - Felsö-Rába-völgy. Szentgotthárd és környéke [Örség Vendvidék - Upper Rába Valley. Szentgotthárd and its Surroundings]. Budapest-Pécs: Dialóg Campus Kiadó.

Bodonczi, László

1999 Az Örség és Vendvidék védett és veszélyeztetett növényei [Protected and Endangered Plants of the Örség and Vendvidék]. Kitaibelia 4(1):169-177.

Bonneuil, Christophe - Fressoz, Jean-Baptiste

2016 The Shock of the Anthropocene: Earth, History and Us. London: Verso.

Borsos, Balázs

2011 A magyar népi kultúra régiói 1. Dunántúl, Kisalföld, Alföld [Regions of Hungarian Folk Culture 1. Transdanubia, Little Hungarian Plain, Great Hungarian Plain]. Budapest: Mérték. 
Brosius, Peter J. - Russell, Diane

2003 Conservation from Above: An Anthropological Perspective on Transboundary Protected Areas and Ecoregional Planning. Journal of Sustainable Forestry 17(1-2):39-66.

ČInČ Juhant, B. - PlanjšEK, M.

2002 O geologiji Pomurja in Goričkega [On the Geology of Mura and Goričko Regions]. In Narava Slovenije. Mura in Prekmurje [Slovenia's Nature. Mura and Prekmurje]. Ljubljana: Prirodoslovni muzej.

Crutzen, Paul J. - Stoermer, Eugene

2000 The "Anthropocene". IGBP Newsletter (41):17-18.

CSAPÓ, Olga

2008 Az Örség térbeli elhatárolási problémái [Problems of Spatial Delimitation in the Örség]. Földrajzi Értesitö LVII(3-4):313-333.

DAnowski, Deborah - Viveiros DE CASTRo, Eduardo

2017 The Ends of the World. Cambridge: Polity Press.

Descola, Philippe

2013 Beyond Nature and Culture. Chicago: Chicago University Press.

Descola, Philippe - PÁlsson, Gísli (eds.)

1996 In Nature and Society: Anthropological Perspectives. London: Routledge.

DEŠNIK, Stanka - DomANJKo, Gregor

2011 Goričko-Raab-Örség - Developing with Nature in a Trilateral Park. In Vasilijević, Maja - Pezold, Tomasz (eds.) Crossing Borders for Nature. European Examples of Transboundary Conservation, 39-41. Gland, Switzerland and Belgrade, Serbia: IUCN Programme Office for South-Eastern Europe. https://portals.iucn.org/library/sites/library/files/ documents/2011-025.pdf (accessed July 17, 2018)

DöмÖTÖR, Sándor

1954 Bakhátas szántás és a nyugat-magyarországi eketípusok [Ridge Plowing and Plow Types in Western Hungary]. Néprajzi Értesítö XXXVI:149-164.

1987 Örség. Szombathely: Örség Baráti Kör.

DöVÉNYI, Zoltán

2010 Magyarország Kistájainak Katasztere [Cadastre of Microregions in Hungary]. Budapest: MTA Földrajztudományi Kutatóintézet.

FARINA, Almo

2000 The Cultural Landscape as a Model for the Integration of Ecology and Economics. BioScience 50(4):313-320.

Franyó, Frigyes - Erhardt, György - Jaskó, Sándor - JuHÁsz, Árpád - SzÉLes, Margit SzüCs, László - WeIn, György

1976 Magyarázó Magyarország 200000-es földtani térképsorozatához [Explanatory Notes on Hungary's 1:200,000 Map Series], L-33-XI. Zalaegerszeg, Budapest: Magyar Állami Földtani Intézet.

GYÖNGYÖSSY, Péter

2016 A táj változásai az Örségi Nemzeti Parkban [Landscape Changes in the Örség National Park]. In BARTHA, Dénes (ed.) Az Orségi Nemzeti Park I, 343-436. Szülőföld Könyvkiadó. 
Hahn, Anke - Konkoly-Gyuro, Éva - Voller, Sonja - BAlÁzs, Pál - Torkar, Gregor ELLIS BuRnET, Julia

2012 Perception of Landscape Changes in Three Trans-Boundary Focus Areas Based on Oral History Surveys with Local Inhabitants, Stakeholders and Experts. TransEcoNet project, project report (WP4, WP6). Sopron: Nyugatmagyarországi Egyetem Kiadó.

Havas, Márta

2016 Harmóniában a tájjal: települések az Örségi Nemzeti Parkban [In Harmony with the Landscape: Settlements in the Örség National Park]. In BarthA, Dénes (ed.) Az Örségi Nemzeti Park II, 455-465. Öriszentpéter: Örségi Nemzeti Park.

Hesz, Roland

2016 Case Study of the Örség-Goričko cooperation. In Crossing the Borders. Studies on Cross-Border Cooperation within the Danube Region, 1-134. Central European Service for Cross-Border Initiatives. European Institute of Cross-Border Studies. http://institute.cesci-net.eu/tiny_mce/uploaded/ CrossingTheBorders_Studies.pdf (accessed July 25, 2018)

HORVAT, Uroš

2009 Naravno in selitveno gibanje prebivalstva v Pomurju po letu 2000 [Natural Increase and Migration Rate of the Population in the Pomurje Region after Year 2000]. In Pomurje: trajnostni regionalni razvoj ob reki Muri [Pomurje: The Sustainable Regional Development of the Mura River], 216-226. Murska Sobota.

HuBER, Ivanka

2013 Seasonal Mobility and Migration in Goričko Region of Prekmurje in the $20^{\text {th }}$ Century. In Bon, Nataša Gregorič - KALČIĆ, Špela - RogeLJA, Nataša (eds.) Ethnographies of Mobility: Conference Programme and Book of Proceedings / International Seminar Scientific Research Centre of the Slovenian Academy of Sciences and Arts, 28-35. Ljubljana: ZRC Publishing House.

ILLÉs, Péter

2016 Hagyományos szőlőmüvelés és gyümölcstermesztés [Traditional Viticulture and Fruit Cultivation]. In Bartha, Dénes (ed.) Az Örségi Nemzeti Park II, 597-627. Öriszentpéter: Örségi Nemzeti Park.

INGOLD, Tim

1986 The Appropriation of Nature: Essays on Human Ecology and Social Relations. Manchester: Manchester University Press.

2000 The Perception of the Environment: Essays on Livelihood, Dwelling and Skill. London: Routledge.

Kaligarič, Mitja - Sedonja, Jožef - Šajna, Nina

2008 Traditional Agricultural Landscape in Goričko Landscape Park (Slovenia): Distribution and Variety of Riparian Stream Corridors and Patches. Landscape and Urban Planning 85(1):71-78.

KÁroLYi, Árpád - Pócs, Tamás

1968 Délnyugat-Dunántúl flórája I [The Flora of Southwestern Transdanubia I.]. In BEnde, Sándor (ed.) Acta Academiae Paedagogicae Agriensis 6, 329-390. Eger. 
KERECSÉNYI, Edit

1994 Távol a hazától... Lendva-vidéki magyar kivándorlók és vendégmunkások [Far from Home... Hungarian Emigrants and Migrant Workers in the Lendva Region]. Lendva.

KeVy, Albert

2016 A turizmus története az embert becsülő Örségben és környékén [The History of Tourism in and Around the People-friendly Örség]. In BARTHA, Dénes (ed.) Az Örségi Nemzeti Park II, 828-871. Szülöföld Könyvkiadó.

KoHN, Eduardo

2013 How Forests Think. Toward an Anthropology Beyond the Human. Berkeley: University of California Press.

KovÁcs, Attila

2013 A muravidéki magyarok a statisztikák tükrében 1869-2011 között [Hungarians in the Mura Region in Light of Statistics 1869-2011]. Ministrstvo za izobraževanje, znanost in šport. https://en.calameo.com/ $\mathrm{read} / 002974134 \mathrm{~b} 2 \mathrm{a} 81 \mathrm{~d} 68 \mathrm{fd} 7 \mathrm{e}$ (accessed June 23, 2018)

2011 Jugoszlávia Kominformból való kizárárásának (ki)hatásai a jugoszláviai magyar és a magyarországi szlovén kisebbségre. Muravidéki és Rába-vidéki példák [The Effects of Yugoslavia's Expulsion from Cominform on the Yugoslavian Hungarian and Hungarian Slovene Minorities. Examples from the Mura and Rába Regions]. In KuPA, László (ed.) Görbe háttal. Interetnikus konfliktusok Közép-Európában a múltban és a jelenben [With Backs Bent: Interethnic Conflicts in Central Europe Then and Now], 125-136. Pécs: Virágmandula Kft.

Kovács J., Attila

1999 Az Örségi Tájvédelmi Körzet növényzetének sajátosságai, ökológiaitermészetvédelmi problémái [Characteristics and Ecological and Conservation Issues of the Fauna of the Örség Nature Reserve]. Kanitzia (53):111-142.

KovÁCs - MEsTerhÁzy, Zoltán

2016a Termelőszövetkezetek az Örségben [Farmers' Cooperatives in the Örség]. In BARThA, Dénes (ed.) Az Örségi Nemzeti Park II, 635-645. Öriszentpéter: Örségi Nemzeti Park.

2016b Az Örség állattenyésztési kultúrája [Animal Husbandry in the Örség]. In Bartha, Dénes (ed.) Az Örségi Nemzeti Park II, 667-690. Öriszentpéter: Örségi Nemzeti Park.

2016c Az Örségi Nemzeti Park jelenkori mezőgazdasága [Current Agriculture in the Örség National Park]. In Bartha, Dénes (ed.) Az Örségi Nemzeti Park II, 652-666. Öriszentpéter: Örségi Nemzeti Park.

Kovacsics, József

2000 Szentgotthárd és környéke. Szentgotthárd környéki, dél-burgenlandi, örségi és vendvidéki falvak és nemzetiségek (1183-1995) [Szentgotthárd and its Surroundings: Villages and Nationalities around Szentgotthárd, Southern Burgenland, the Örség and Vendvidék Regions]. Település- és népességtörténeti lexikon. Budapest: Központi Statisztikai Hivatal.

KozÁr, Mária

2000 Felsőszölnök. Budapest: Száz Magyar Falu Könyvesháza. 


\section{KozÁR, Mária}

1994 A magyarországi szlovének demográfiai sajátosságai [The Demographic Characteristics of Slovenes in Hungary]. In Kovacsics, József (ed.) Magyarország nemzetiségeinek és a szomszédos államok magyarságának statisztikája 1910-1990. Az 1992. szeptember 2-5. között Budapesten megrendezett Nemzetiségi Statisztikai Konferencia elöadásai [Statistics on Hungary's Minorities and on the Hungarians in Neighboring Countries 19101990. Presentations of the Minority Statistics Conference Held in Budapest, September 2-5, 1992], 333-338. Budapest: Központi Statisztikai Hivatal.

Kozorog, Miha

2015 Živali, varovano območje in rekreacija v naravnem okolju : teoretske in praktične variante s samopremislekom [Wildlife, Protected Areas, and Recreation in the Natural Environment: Theoretical and Practical Variations with Self-reflection]. Traditiones 44(1):117-134.

KöRÖSI, Ádám - SzEnTIRMAI, István - BATÁRY, Péter - KövÉR, Szilvia - ÖRvÖssY, Noémi Peregrovits, László

2014 Effects of timing and Frequency of Mowing on the Threatened Scarce Large Blue Butterfly - A Fine-Scale Experiment. Agriculture, Ecosystems and Environment (196):24-33.

KöRÖSI, Ádám - SzentiRMAI, István - ÖRvÖssy, Noémi - Kövér, Szilvia - BATÁRY, PéterPeregovits, László

2009 A kaszálás hatásainak vizsgálata a vérfü hangyaboglárka (Maculinea teleius) populációira - egy kezelési kísérlet első tapasztalatai [Examining the Effects of Mowing on the Population of the Scarce Large Blue (Maculinea teleius) Initial Experiences of a Trial Treatment]. Természetvédelmi Közlemények (15):257-268.

LAJOS, Veronika

2014 Alkalmazott szemléletủ társadalomtudomány: társadalmi részvétel, kollaboratív etnográfia és akciókutatás [Applied Social Science: Social Participation, Collaborative Ethnography, and Action Research]. Néprajzi Látóhatár 23(1-2):25-49.

LAMPIČ, Barbara - MrAK, Irena - PoTOČNIK SLAVIČ, Irma

2015 Transformation of Rural Slovenia: The Pomurje Region in Search of New Development Paths. In McDonagh, John - Nienaber, Birte - Woods, Michael (eds.) Globalization and Europe's Rural Regions, 125-142. London-New York: Routledge.

LÁNYI, András

2010 Miért fenntarthatatlan, ami fenntartható? A környezetbarát gazdálkodás és a közösségi vállalkozás esélyei egy aprófalvas régióban [Why is the Sustainable Unsustainable? Environmentally Friendly Farming and Community Ventures in a Region of Small Villages]. Szociológia Szemle 20(2):94-131.

LATOUR, Bruno

2013 Facing Gaia: Eight Lectures on the New Climatic Regime. London: Polity. LeBE, Sonja Sibila

N.d. TourismDevelopmentinProtectedAreas-aBlessingoraCurse? $\mathrm{http}: / / \mathrm{www}$.irdo. si/skupni-cd/cdji/cd-irdo-2010/images/3-6-6-lebe.pdf (accessed July 20, 2018) 
MaLAČIČ, Janez

2011 Demografske značilnosti območja Krajinskega parka Goričko v širših okvirih Prekmurja in Slovenije [Demographic Situation in Goričko Landscape Park from the Perspectives of Prekmurje and Slovenia]. Anali Pazu 1(2):155-160.

Markovics, Tibor

2016 Az Örségi Nemzeti Park múltja és jelene [The Past and Present of the Örség National Park]. In Bartha, Dénes (ed.) Az Örségi Nemzeti Park I, 11-37.

MENDÖL, Tibor Szülőföld Könyvkiadó.

1963 Általános településföldrajz [General Urban Geography]. Budapest: Akadémiai Kiadó.

MÉszÁros, Csaba

2015 A kvalitatív kutatás esélyei a magyar-osztrák-szlovén hármas határ térségében [Opportunities for Qualitative Research in the Triple Border Region of Hungary-Austria-Slovenia]. In Turai, Tünde (ed.) Hármas határok néprajzi értelmezésben [An Ethnographic Interpretation of Tri-Border Areas], 73-84. Budapest: MTA BTK Néprajztudományi Intézet.

MóD, László

2015 „A határ, ami elválaszt és összeköt.” Emlékművek és ünnepek a magyarszlovén államhatáron [The Border that Separates and Connects: Memorials and Holidays on the Hungarian-Slovenia State Border]. In TurAI, Tünde (ed.): Hármas határok néprajzi értelmezésben [An Ethnographic Interpretation of Tri-Border Areas], 95-104. Budapest: MTA BTK Néprajztudományi Intézet.

Moнos, Mária

2008 A Rábától a Muráig. A magyar-szlovén határtérség történeti-földrajzi vizsgálata [From the Rába to the Mura: A Historic-Geographic Study of the Hungarian-Slovenian Border Region]. Szombathely: a Nyugat-magyarországi Egyetem Savaria Egyetemi Központ Szláv Filológiai Intézete.

Moore, Amelia

2015 Islands of Difference: Design, Urbanism, and Sustainable Tourism in the Anthropocene Caribbean. The Journal of Latin American and Caribbean Anthropology 20(3):513-532.

Moore, Jason W.

2016 Introduction. Anthropocene or Capitalocene? Nature, History, and the Crisis of Capitalism. In Moore, J. W. (ed.) Anthropocene or Capitalocene? Nature, History, and the Crisis of Capitalism, 1-10. Oakland: Kairos - PM Press.

Mukics, Mária

2003 A magyarországi szlovének [Slovenes in Hungary]. Budapest: Press Publica.

Munda HiRnöK, Katalin

2011 Deportálások Magyarország nyugati határszélén az 1950-es években [Deportations in the Western Borderlands of Hungary in the 1950s]. In KupA, László (ed.) Görbe háttal. Interetnikus konfliktusok Közép-Európában a múltban és a jelenben [With Backs Bent: Interethnic Conflicts in Central Europe Then and Now], 137-145. Pécs: Virágmandula Kft. 
2013 Represija nad Slovenci v Porabju v času Rákosijevega režima (1948-1956) [Repression of the Rába region Slovenians in the Rákosi era]. Prispevki za novejšso zgodovino 53(1):201-212.

2016 Življenje porabskih slovenskih povojnih deportirancev po zaprtju delovnih taborišč [Life of Slovenian post-war deportees after the closure of labor camps]. Etnolog. Glasnik Slovenskega etnografskega muzeja 26:81-101.

Munda HirnöK, Katalin - MedvešEK, Mojca

2016 Čezmejna mobilnost porabskih Slovencev [Cross-Border Mobility of Rába Region Slovenians]. Traditiones 45(3):91-113.

NAGY, Mária - SAÁd, József

2013 „Péntek volt és 23”. Kitelepitések 1950-1953 között a Vas megyei határsávból ["It was Friday the 23 ${ }^{\text {rd }}$ ": Expatriations from the Vas County Borderlands 19501953]. Budapest: Telepesek Társadalmi Múzeum Alapítvány - Argumentum Kiadó és Nyomdaüzem.

NAGY, Zoltán

1999 Egy történeti kistáj, az Örség néprajzi határainak vizsgálata [The Ethnographic Borders of the Örség, a Historical Microregion]. Savaria - A Vas Megyei Múzeumok Értesitöje 22(4):145-180.

2016 Hagyományos földművelés és állattartás [Traditional Agriculture and Animal Husbandry]. In Bartha, Dénes (ed.) Az Örségi Nemzeti Park II, 549-560. Öriszentpéter: Örségi Nemzeti Park.

Pataki, György - Bodorkós, Barbara - Balázs, Bálint - Bela, Györgyi - Kelemen, Eszter - Mérö, Ágnes

2011 Tájfajták védelmében: részvételi akciókutatás az Örség-Vendvidéken [In the Defense of Landraces: Participatory Action Research in the Örség and Vendvidék Regions]. In PATAKI, György - VÁRI, Anna (eds.) Részvétel-akciókutatás (Magyarországi tapasztalatok a részvételi-, akció- és kooperatív kutatásokból) [Participation-Action-Research (Hungarian Experiences in Participatory, Action, and Cooperative Research)], 9-27. Budapest: MTA SZKI.

Peterlin, Marko - Simoneti, Maja

2016 The Trilateral Nature Park Goričko-Raab-Örség. A Project-Based Mode of Territorial Governance. In Schmitt, Peter - VAn Well, Lisa (eds.) Territorial Governance across Europe. Pathways, Practices and Prospects, 189-203. London-New York: Routledge.

Poschlod, Peter - Kiefer, S. - Tränkle, U. - Fischer, S. - Bonn, S.

1998 Plant Species Richness in Calcareous Grasslands as Affected by Dispersability in Space and Time. Applied Vegetation Science 1(1):75-91.

Pósfai H., János

1974 “Rezervátumok" [Reserves]. Életünk 12(5):436-443.

PuRDY, Jedediah

2015 After Nature. A Politics for the Anthropocene. Cambridge: Harvard University Press.

Simon, József

1980 Vas megye tájvédelmi körzetei [Conservation Areas in Vas County]. Honismeret 8(6):24-25. 
SoNKOLY, Gábor

2016 Bolyhos tájaink. A kulturális örökség történeti értelmezései [Blurry Landscapes: Historical Interpretations of Cultural Heritage]. Budapest: ELTE Eötvös Kiadó.

StefFen, Will - Crutzen, Peter - McNeill, John R.

2007 The Anthropocene: Are Humans Now Overwhelming the Great Forces of Nature? Ambio 36(8):614-621.

SzÉPLIGETI, Mátyás

2015 Természetvédelmi kezelést támogató botanikai szempontú vizsgálatok az Örségi Nemzeti Park gyepterületein [Botanical Studies in Support of Nature Conservancy in the Grasslands of the Örség National Park]. PhD dissertation. Sopron: Nyugat-magyarországi Egyetem, Roth Gyula Erdészeti és Vadgazdálkodási Tudományok Doktori Iskolája.

SzÉPLigeti, Mátyás - Tóth, Antónia

2016 Az Örségi Nemzeti park növényvilága [The Flora of the Örség National Park]. In Bartha, Dénes (ed.) Az Örségi Nemzeti Park I, 145-181. Öriszentpéter: Örségi Nemzeti Park.

TAYLOR, Ken

2012 Landscape and Meaning: Context for a Global Discourse on Cultural Landscape Values. In TAYLOR, Ken - LenNON, Jane L. (eds.) Managing Cultural Landscapes, 21-44. Abingdon: Routledge.

Taylor, Ken - St. Clair, Archer - Mitchell, Nora J. (eds.)

2015 Conserving Cultural Landscapes: Challenges and New Directions. London: Routledge.

TóTH, János

1971 Az Örségek népi épitészete [Folk Architecture in the Örség]. Budapest: Müszaki Könyvkiadó.

Turai, Tünde - MÉszÁros, Csaba (eds.)

2015 Hármas határok néprajzi nézetben [An Ethnographic Perspective on TriBorder Areas]. Budapest: MTA BTK Néprajztudományi Intézet.

Víg, Károly

1999 Vas megye élővilágának megismerése, jelenkori természeti értékei [Wildlife and its Current Natural Values in Vas County]. Savaria - A Vas Megyei Múzeumok Értesitője 25(2):7-82.

2003 Zoological Research in Western Hungary. Szombathely: Vas County Body of the Hungarian Academy of Sciences.

World Conservation Monitoring Centre

1996 Phengaris nausithous. The IUCN Red List of Threatened Species 1996: e.T12662A3371835.

http://dx.doi.org/10.2305/IUCN.UK.1996.RLTS.T12662A3371835.en (accessed July 28, 2018). 
Ágota Lídia Ispán is a research fellow at the Institute of Ethnology, Research Centre for the Humanities, Hungarian Academy of Sciences. She holds a PhD in Historical Science (Social and Economic History). Her research interests focus on the lifestyle changes in the framework of socialist modernization, the socialist city, history of everyday life, village power elite. E-mail: ispan.agota@btk.mta.hu

Dániel Babai is a research fellow at the Institute of Ethnology, Research Centre for the Humanities, Hungarian Academy of Sciences. He received his PhD at the University of Pécs in 2014; his dissertation was titled Botanical and Ethnoecological Investigation of Mountain Vegetation in Ghymes (Eastern Carpathians, Romania). He specializes in ethnoecology as related to extensive land use systems in rural communities. E-mail: babai.daniel@btk.mta.hu

László Mód is an assistant professor at the Department of Ethnology and Cultural Anthropology, University of Szeged. His main interest and research fields are museology, modern wine culture (wine festivals, wine clubs, representation of wine heritage). E-mail:mod@hung.u-szeged.hu

Viktor Ulicsni is a research assistant at the Institute of Ecology and Botany, Ecological Research Centre, Hungarian Academy of Sciences. He is an ethnozoologist and ecologist working in the Carpathian Basin and Moldova. E-mail: ulicsni.viktor@okologia.mta.hu

Csaba Mészáros is a research fellow at the Institute of Ethnology, Research Centre for the Humanities, Hungarian Academy of Sciences. He works in the department of social anthropology and has been involved in a number of domestic and international research projects focusing on border communities at the Slovenian-Hungarian border. His main foci of interest cover a wide range of topics, from ecological anthropology to network analysis. Recently he has done research on the relationship between landscapes (such as meadows and lakes) and humans. E-mail: meszaros.csaba@btk.mta.hu 